\title{
Stability of Cephaloridine and Cephalothin to Staphylococcal Penicillinase
}

\author{
By J. M. T. HAMILTON-MILLER* AND JILL RAMSAY \\ Department of Bacteriology, Guy's Hospital Medical School, London, S.E.I
}

(Accepted for publication 28 June 1967)

\begin{abstract}
SUMMARY
The rates of destruction of benzylpenicillin, cephaloridine, cephalothin and (in some cases) cloxacillin by cocci from induced cultures of 17 strains of Staphylococcus aureus were measured. Rates of destruction of cephaloridine, relative in each case to those of benzylpenicillin, by the Io methicillinresistant strains were not significantly different from those by the 7 methicillinsensitive strains. $V_{\max }$ for cephaloridine and cephalothin were about $0.2 \%$ and $0.009 \%$, respectively, that for benzylpenicillin; cloxacillin was destroyed still more slowly. The inactivation of the cephalosporins is almost certainly brought about by the action of penicillinase. Notwithstanding its greater stability to staphylococcal penicillinase, cephalothin is less effective than cephaloridine at suppressing the growth of the methicillin-resistant strains, although there is cross-resistance between methicillin, cloxacillin, cephalothin and cephaloridine.
\end{abstract}

\section{INTRODUCTION}

Cephaloridine, a semisynthetic cephalosporin introduced for therapeutic use in 1964 (Muggleton, O'Callaghan \& Stevens, 1964), has been shown in many laboratory trials to be highly effective in vitro against penicillinase-producing strains of Staphylococcus aureus. The most comprehensive of these studies to date seems to be that made by Vymola \& Hejzlar (I966), who studied the sensitivities of 800 strains of clinically isolated $S$. aureus which were benzylpenicillin-resistant. The general conclusion reached by the workers who did laboratory trials is that cephaloridine is more active against staphylococci than is cloxacillin, especially in the presence of serum (Barber \& Waterworth, 1964), and that it is at least as effective as cephalothin, in vivo and in vitro (Thornton \& Andriole, 1966). Three recent papers (Ridley \& Phillips, 1965; Benner, Bennett, Brodie \& Kirby, I965; Hye-Knudsen, 1966) have indicated that cephaloridine is inactivated relatively rapidly by staphylococcal penicillinase, and from the first two of these papers it might be concluded that methicillin-resistant strains possess some special ability to destroy cephaloridine; however, all three reports give only qualitative results. The present work was done to determine whether methicillin-resistant $S$. aureus strains inactivate cephaloridine and cephalothin more rapidly, either relatively or absolutely, than do methicillin-sensitive strains. Quantitative measurements were made of the breakdown of benzylpenicillin, cephaloridine and cephalothin, by ten naturally occurring methicillin-resistant and seven methicillin-sensitive $S$. aureus strains. Crossresistance between methicillin, cephaloridine and cephalothin was also examined.

* Present address: Sir William Dunn School of Pathology, Oxford. 


\section{METHODS}

Bacterial strains. The I7 strains of Staphylococcus aureus used in this investigation are listed in Table I, with place of origin and phage-type (we are grateful to $\mathrm{Mr} \mathrm{J}$. Gibb for phage-typing strains $1735,1736,6467,33,63,69$ ). The division into 'methicillinresistant' and 'methicillin-sensitive' was originally made on the basis of the reported methicillin sensitivities of the strains, later substantiated by disc and plate methods as described below.

Table I. Strains of Staphylococcus aureus used

\begin{tabular}{|c|c|c|c|c|}
\hline Strain & Source & Reference & $\begin{array}{l}\text { Pattern of } \\
\text { resistance* }\end{array}$ & Phage type \\
\hline $\left.\begin{array}{l}1735 \\
1736 \\
6467 \\
6637\end{array}\right\}$ & Carshalton & Stewart \& Holt, 1963 & $\begin{array}{l}\mathrm{PN}, \mathrm{s}, \mathrm{T}, \mathrm{CB} \\
\mathrm{OB}, \mathrm{CR}\end{array}$ & $75 / 77$ \\
\hline & Copenhagen & Eriksen \& Erichsen, 1963 & $\begin{array}{l}\mathrm{PN}, \mathrm{S}, \mathrm{T}, \mathrm{CB} \\
\mathrm{OB}, \mathrm{CR}\end{array}$ & $6 / 75 / 77$ \\
\hline $\left.\begin{array}{l}10395 \\
10396 \\
13136 \\
13137 \\
14668\end{array}\right\}$ & Colindale & Jevons, I96I & $\begin{array}{l}\mathrm{PN}, \mathrm{S}, \mathrm{T}, \mathrm{CB} \\
\mathrm{OB}, \mathrm{CR}\end{array}$ & $7 / 47 / 53 / 54 / 75 / 77$ \\
\hline $\left.\begin{array}{ll}\text { E3 } & \\
\text { GALT } \\
& 33\end{array}\right\}$ & $\begin{array}{l}\text { Guy's } \\
\text { Hospital }\end{array}$ & Knox, I960 & $\begin{array}{l}\text { PN, S, T } \\
\text { PN, T } \\
\text { PN, S }\end{array}$ & $\begin{array}{l}77 \\
52 / 8 \mathrm{o} /+ \\
54 / 75 / 77 / 83 \mathrm{a}\end{array}$ \\
\hline $\left.\begin{array}{l}63 \\
69\end{array}\right\}$ & Mancheste & $\begin{array}{l}\text { Fairbrother, Parker \& Eaton, } \\
\text { I954 }\end{array}$ & PN, S, T & Not typable \\
\hline $\left.\begin{array}{l}8511 \\
8534\end{array}\right\}$ & NCTC & - & $\begin{array}{l}\text { PN } \\
\text { PN, }, ~\end{array}$ & $\begin{array}{l}53 \\
75 / 77\end{array}$ \\
\hline
\end{tabular}

* Strains were resistant (disc technique) to the drugs specified: $\mathrm{PN}=$ benzylpenicillin; $\mathrm{s}=$ streptomycin; $\mathbf{T}=$ tetracycline; $\mathbf{C B}=$ methicillin; $\mathrm{OB}=$ cloxacillin; $\mathrm{CR}=$ cephaloridine. See Methods.

Sensitivity testing. Organisms were incubated at $37^{\circ}$ overnight in infusion broth (Southern Group Laboratories, Hither Green, London, S.E. I3); O I m1. of each culture was spread on Oxoid sensitivity agar to give a uniform lawn. An Oxoid Multodisk (code II-I4D), or an appropriate individual sensitivity disc, was then laid on the surface of the agar, and the plate incubated at $37^{\circ}$ overnight. The compounds tested were (amount in each disc shown in parentheses): chloramphenicol $(50 \mu \mathrm{g}$.), erythromycin $(50 \mu \mathrm{g}$.), novobiocin (30 $\mu \mathrm{g}$.), oleandomycin (Io $\mu \mathrm{g}$.), streptomycin (25 $\mu \mathrm{g}$.),

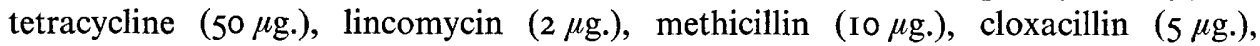
cephaloridine $(5 \mu \mathrm{g}$.). Strains which produced confluent growth up to the edge of a disc were taken to be (qualitatively) resistant to the drug contained in that disc.

Penicillins and cephalosporins. The following compounds were used as substrates, antibacterial agents or inducing agents: benzylpenicillin (Crystapen; from Glaxo Ltd., Greenford, Middlesex); cephaloridine (Ceporin) and cephalothin (both generously given by Glaxo Laboratories Ltd.); methicillin (Celbenin) and cloxacillin (Orbenin)both generously given by Beecham Research Laboratories, Betchworth, Surrey.

Culture methods and penicillinase preparations. Each strain was grown overnight statically at $37^{\circ}$ in several $20 \mathrm{ml}$. amounts of infusion broth (containing methicillin $0.5 \mu \mathrm{g} . / \mathrm{ml}$. as inducing agent), each $20 \mathrm{ml}$. sample being in a separate $100 \mathrm{ml}$. bottle. 
Cultures of each strain were pooled, and organisms were harvested by centrifugation ( $3000 \mathrm{~g}$ for $20 \mathrm{~min}$.). The pellet of cocci was then resuspended in a volume of sterile sodium phosphate buffer $(25 \mathrm{mM}, \mathrm{pH} 7 \cdot 4)$ equal to half that of the original pooled culture. Such a preparation is called $2 \times$ 'normal', meaning that the cell concentration of organisms was double that of the original overnight culture; a 'normal' suspension usually contained $4-7 \times 10^{8} \mathrm{cocci} / \mathrm{ml}$. The resulting suspension was counted $(0 \cdot \mathrm{Iml}$. samples of a $10^{-6}$ dilution were spread in duplicate or triplicate on blood agar plates, incubated at $37^{\circ}$ overnight, and the colonies counted), and separate samples were assayed against benzylpenicillin, cephaloridine, cephalothin and (in some cases) cloxacillin, as described below.

Assay methods. Activity against benzylpenicillin was assayed at $37^{\circ}$, against samples of cocci which had been inactivated by treatment with mM-sodium $p$-chlormercuribenzoate, by the hydroxylamine method as described by Knox \& Smith (1962); the coccal concentration was $0.22 \times$ normal, and the substrate concentration was initially $4.6 \mathrm{~mm}(\mathrm{I} \cdot 7 \mathrm{mg} . / \mathrm{ml}$.). Activities against cephaloridine, cephalothin and (where applicable) cloxacillin were assayed by a microbiological method: appropriate amounts of coccal suspension, substrate solution and sterile buffer were placed in bottles, to a final volume of $20 \mathrm{ml}$., and incubated at $37^{\circ}$. At intervals ( 2 and $4 \mathrm{hr}$ after the start of the assay for cephaloridine, 3 and $6 \mathrm{hr}$ for cephalothin and cloxacillin), $5 \mathrm{ml}$. samples were withdrawn, the cocci removed by centrifugation ( $3000 \mathrm{~g}$ for $20 \mathrm{~min}$.) and the supernatant fraction placed in a sterile bottle in a deep-freeze cabinet $\left(-20^{\circ}\right)$. These fractions did not contain detectable penicillinase activity (see below). When all the samples were to hand (after $6 \mathrm{hr}$ ) the concentration of antibiotic in each one was assayed by the cup-plate method, with Sarcina lutea NCTC 8340 (ATCC 934I) as test organism (Knox \& Smith, 1963). The following controls were run in parallel with the assays: compound in absence of staphylococci, and compound in presence of a suitable dilution of Staphylococcus aureus OxFORD. (These two controls always gave identical results.) Coccal concentrations and initial substrate concentrations were as follows: cephaloridine $5 \mu \mathrm{g} . / \mathrm{ml}$., cocci at $0.05 \times$ normal; cephalothin $5 \mu \mathrm{g}$./ $\mathrm{ml}$., cocci at $\mathrm{I} \times$ normal; cloxacillin $\mathrm{Io} \mu \mathrm{g}$. $/ \mathrm{ml}$., cocci at $\mathrm{I} \times$ normal.

Graphs were constructed of drug concentration remaining against time, and the nett value of the rate of destruction (as $\mathrm{m} \mu$ moles $/ \mathrm{hr} / \mathrm{ml}$.) of each drug for every strain was calculated from these; all rates were then corrected for coccal concentration, to an arbitrary figure of $10^{9} \mathrm{cocci} / \mathrm{ml}$.

In preliminary experiments, sample solutions of benzylpenicillin (containing between 400 and $1000 \mu \mathrm{g} . / \mathrm{ml}$.) were assayed in parallel by the hydroxylamine and microbiological techniques. As the results obtained by the two methods showed satisfactory numerical agreement, it was considered legitimate to compare the results obtained with benzylpenicillin using the chemical assay with those obtained with the other compounds using the biological assay.

Control experiments verified that all detectable traces of penicillinase were removed by the centrifugation procedure used during the bioassay technique; $5 \mathrm{ml}$. samples were taken from mixtures of cephaloridine or cephalothin and induced cocci which had been incubated at $37^{\circ}$ for $2 \frac{1}{2} \mathrm{hr}$. Each sample was centrifuged and the supernatant fraction removed; a portion of each fraction was assayed immediately, while the remainder was incubated at $37^{\circ}$; after $18 \mathrm{hr}$ and $24 \mathrm{hr}$ portions of each sample were again removed and assayed. Control samples (put up in the absence of cocci) were 
treated in a similar way. In no case did the samples which had been originally incubated in the presence of cocci contain less intact cephalosporin than the corresponding control samples: it was hence deduced that enzymatic breakdown of the cephalosporins ceased when the cocci were removed.

Chromatography. (a) Cephaloridine and cephalothin were applied by a calibrated loop in $100 \mu \mathrm{g}$. amounts to Whatman no. I paper, and the chromatogram run overnight, descending, in an acid solvent ( $n$-butanol + acetic acid + water, $\mathbf{I} 2+3+5$ by vol.); spots were visualised by inspection under ultraviolet radiation, when the cephalosporins were distinguishable by their yellow fluorescence.

(b) Chromatograms to be developed by bio-autography were run on specially cut Whatman no. I papers ( 9 in. wide $\times I_{3}$ in. long): 3 in. strips were left intact at the top and bottom of the paper, and strips were cut out of the middle part to leave 4 strips 0.5 in. wide. Samples (containing approximately $\mathrm{I} \cdot 5 \mu \mathrm{g}$. of intact drug, for optimal results) were applied to the top of each strip, and the chromatogram was then run $(2-4 \mathrm{hr})$ in either the acid solvent described above, an alkaline solvent ( $n$-butanol + pyridine + water, equal vols.), or a neutral solvent (organic phase of $n$-butanol+ ethanol + water, $4+\mathrm{I}+5$ by vol.). Papers were dried until solvent smell was not noticeable, the strips were cut out and laid on nutrient agar containing $2 \%$ by volume of an overnight shaken broth culture $\left(37^{\circ}, 80\right.$ cyc./min.) of Sarcina lutea NCTC 8340 , in Perspex plates ( $12 \times$ IO in., containing $250 \mathrm{ml}$. medium). The plates were incubated at $37^{\circ}$ overnight, and $R_{F}$ values calculated from the distance of the middle of each zone of inhibition from the origin.

\section{RESULTS}

\section{Sensitivity tests}

Disc tests established that no strain was resistant to chloramphenicol, erythromycin, novobiocin, oleandomycin or lincomycin; all strains except 85I I, 8534, GALT and 33 showed multiple resistance (i.e. resistance to at least benzylpenicillin, streptomycin and tetracycline). Methicillin, cloxacillin and cephaloridine discs gave no zones of inhibition when tested against methicillin-resistant strains, while all the methicillinsensitive strains showed large zones of inhibition (greater than $15 \mathrm{~mm}$. in diameter) around these discs (Table I).

Methicillin-resistant strains contain a proportion of individual bacteria with increased intrinsic resistance to the drug (Sutherland \& Rolinson, 1964). To determine to what extent this phenomenon also applied to the strains used here, $0 \cdot 1 \mathrm{ml}$. samples of suitably diluted preparations from overnight broth cultures of the methicillinresistant Staphylococcus aureus strains were plated on nutrient agar (a $10^{-6}$ dilution was used), and nutrient agar containing $\mathrm{Io} \mu \mathrm{g} . / \mathrm{ml}$. methicillin $\left(\mathrm{IO}^{-5}\right.$ and $\left.\mathrm{IO}^{-6}\right)$, Io $\mu \mathrm{g}$. $/ \mathrm{ml}$. cephalothin $\left(\mathrm{IO}^{-5}\right)$, or $10 \mu \mathrm{g} . / \mathrm{ml}$. cephaloridine $\left(\mathrm{IO}^{-4}\right.$ and $\left.\mathrm{IO}^{-5}\right)$. Plates were incubated for $\mathrm{I} 5 \mathrm{hr}$, the colonies counted, and those plates on which few (or no) colonies were observed were incubated for a further $24 \mathrm{hr}$ and again counted. From these counts, the proportions of cocci able to grow at each concentration of the three drugs were calculated; the results are shown in Table 2. In most cases more than half the cocci were able to grow in the presence of methicillin $10 \mu \mathrm{g} . / \mathrm{ml}$., and a significant proportion also grew in the presence of cephalothin $10 \mu \mathrm{g} . / \mathrm{ml}$.; far fewer cocci possessed intrinsic resistance to cephaloridine. However, only in the case of strain 6467 
were no cephaloridine-resistant clones observed. In three cases, with strains 5974, 6637 , I3I37, semiconfluent growth was seen on the cephaloridine-containing plates inoculated with the $1 \mathrm{I}^{-4}$ dilution, but no colonies, or at best very few, were observed at the $10^{-5}$ dilution. This phenomenon was interpreted as being due to an inoculumsize effect, caused by the destruction of the drug by the larger inoculum. On plates containing methicillin or cephalothin, colonies were usually countable after incubation for $15 \mathrm{hr}$, while on the plates containing cephaloridine the further $24 \mathrm{hr}$ period of incubation was necessary before counts could be made. In common with the findings of earlier workers (Barber, 1964; Sutherland \& Rolinson, 1964), there was a considerable degree of colonial variation on plates containing methicillin, cephalothin or cephaloridine.

\section{Table 2. Intrinsic cross-resistance between methicillin, cephaloridine and cephalothin}

Dilutions of overnight broth cultures $\left(3.9 \times 10^{8}\right.$ to $8.6 \times 10^{8}$ bacteria $/ \mathrm{ml}$.) were plated out on solid medium alone and in the presence of the 3 compounds shown, at $10 \mu \mathrm{g} . / \mathrm{ml}$.

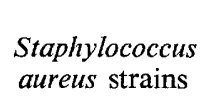

1735
1736
6467
6637
5974
10395
10396
13136
13137
14668



Proportion (\%) of bacteria capable of growth

$\begin{array}{rcr}45 & 0.6 & 46 \\ 44 & 0.5 & 25 \\ 7 \text { I } & 0 . \mathrm{I} & 40 \\ 77 & * & 31 \\ 45 & * & 44 \\ 100 & 0.2 & 46 \\ 26 & 0.7 & 100 \\ 80 & \text { II } & 38 \\ 98 & * & 100 \\ 56 & 0.3 & 40\end{array}$

* In these cases, heavy growth occurred with $10^{-4}$ dilution, no growth with $10^{-5}$ dilution.

Samples (O. I ml.) of overnight cultures of the methicillin-sensitive strains were also spread, undiluted, on plates containing methicillin, cephalothin or cephaloridine at Io $\mu \mathrm{g} . / \mathrm{ml}$.; no growth was observed in any case (the inoculum size was at least $3 \times 10^{7}$ bacteria/plate). Thus, the results obtained by the disc technique were confirmed by the results of the plate tests. There was cross-resistance between methicillin and the two semi-synthetic cephalosporins, although it appeared that cephalothin was less active than cephaloridine against methicillin-resistant strains.

\section{Destruction of $\beta$-lactam drugs}

The rates of destruction of benzylpenicillin, cephaloridine and cephalothin by the I 7 staphylococcal strains used here are given in Table 3. Cephaloridine was inactivated at about the same rate, relative to benzylpenicillin, by the methicillin-resistant and methicillin-sensitive strains alike (mean values $0.18 \%$, S.D. 0.044 and $0.18 \%$, S.D. 0.059 respectively; difference between means not significant). Cephalothin was Io-20 times less labile than cephaloridine, and there was no significant difference between methicillin-resistant and methicillin-sensitive strains (mean values $0.010 \%$, S.D. 0.0023 , and $0.0087 \%$, S.D. 0.0017 , respectively). Similarly, there was no significant 
difference between the I3 multiple-resistant strains and the 4 which did not show multiple-resistance, in respect of their relative abilities to inactivate the cephalosporins. In the 6 cases where the destruction of cloxacillin was measured at the same time as that of the cephalosporins, cloxacillin was found to be even more stable than cephalothin.

\section{Table 3. Rates of destruction of various compounds by induced preparations of 17 Staphylococcus aureus strains}

Figures are given as m $\mu$ moles substrate destroyed $/ \mathrm{ml} . / \mathrm{hr}$ at $37^{\circ}$ in phosphate buffer $(\mathrm{pH} 7 \cdot 4)$; all values are corrected to a coccal concentration of $10^{9}$ cocci $/ \mathrm{ml}$. Figures in parentheses are rates relative to benzylpenicillin (rate for benzylpenicillin put at Ioo for each strain).

\begin{tabular}{|c|c|c|c|c|}
\hline & $\begin{array}{l}\text { Benzyl- } \\
\text { penicillin }\end{array}$ & Cephaloridine & Cephalothin & Cloxacillin \\
\hline & \multicolumn{4}{|c|}{ Rates of destruction ( $\mathrm{m} \mu$ moles $/ \mathrm{hr}$ ) } \\
\hline 1735 & 33,200 & $72(0.217)$ & $3.7(0.011)$ & $I \cdot 4(0.00422)$ \\
\hline 1736 & 40,500 & $79(0.195)$ & $3.4(0.00835)$ & $2 \cdot I(0.005)$ \\
\hline 6467 & 52,300 & $106(0.203)$ & $6.2(0.0119)$ & - \\
\hline 6637 & $41 \cdot 200$ & $84(0.204)$ & $3.8(0.00923)$ & $I \cdot 2(0 \cdot 00292)$ \\
\hline 5974 & 28,400 & $33(0 \cdot 116)$ & $2.9(0.0102)$ & $1 \cdot 2(0.00422)$ \\
\hline 10395 & 26,800 & $6 I(0.228)$ & $3.8(0.0140)$ & $I \cdot 2(0.0045)$ \\
\hline 10396 & 36,400 & $63(0 \cdot 173)$ & $3.0(0.00825)$ & - \\
\hline 13136 & 32,500 & $67(0 \cdot 203)$ & $4.0(0.0124)$ & $I \cdot 3(0 \cdot 004)$ \\
\hline 13137 & 47,500 & $70(0 \cdot 148)$ & 4.8 (0.010I) & - \\
\hline 14668 & 31,800 & $35(0.110)$ & $\mathrm{I} \cdot 95(0.006 \mathrm{I})$ & - \\
\hline E3 & 33,400 & $61(0.183)$ & $2 \cdot 3(0.007)$ & - \\
\hline GALT & 94,100 & $94(0.099)$ & $8.8(0.0094)$ & - \\
\hline 33 & 36,200 & $74(0.204)$ & $3.7(0.0102)$ & - \\
\hline 63 & 46,800 & I $20(0.256)$ & $4 . \mathrm{I}(0.0088)$ & 一 \\
\hline 69 & 49,800 & $115(0.231)$ & $5.1(0.0102)$ & - \\
\hline $85 \mathrm{II}$ & 68,100 & $78(0.1 \mathrm{I})$ & $6.5(0.0092)$ & - \\
\hline 8534 & I 5,600 & $25(0.163)$ & $0.9(0.0059)$ & - \\
\hline
\end{tabular}

It seemed unlikely that induction of penicillinase would take place during the incubation period (up to $6 \mathrm{hr}$ ), since the cocci were suspended in a non-nutrient medium (in fact washed suspensions in buffer were used rather than whole broth cultures deliberately to avoid induction occurring during this incubation period). To test this point, the penicillinase activities of coccal suspensions were measured against benzylpenicillin before and after incubation for $6 \mathrm{hr}$ with cloxacillin $10 \mu \mathrm{g} . / \mathrm{ml}$; ; in every case the activities of the two suspensions were precisely the same. It was confirmed that cloxacillin $10 \mu \mathrm{g} . / \mathrm{ml}$. did not inhibit staphylococcal penicillinase, so that it may be concluded that induction of penicillinase did not occur during the assay procedure adopted.

Since cephaloridine and cephalothin have extremely high affinities for staphylococcal penicillinase (of the order of $0.05 \mu \mathrm{M}$; Hamilton-Miller, I966, and unpublished results), the rates of destruction given in Table 3 are indistinguishable from the values of $V_{\max }$; the same argument applies for benzylpenicillin ( $K_{m}$ approximately $\mathrm{I} 5 \mu \mathrm{M}$ ), but not for cloxacillin, which is known to have a very low affinity for staphylococcal penicillinase (Nayler et al. 1962). The rates of cloxacillin destruction given in Table 3 thus bear no relation to the $V_{\max }$ values for this compound. The argument in this paragraph presupposes that the inactivation of all these drugs was due to penicillinase (see next section). 


\section{Nature of destruction of cephalosporins}

It can be seen from Table 3 that there seems to be a correlation between the rates of hydrolysis of benzylpenicillin and of the two cephalosporins. If this could be established, it would be excellent circumstantial evidence for the proposition that penicillinase is responsible for the destruction of the cephalosporins. The correlation was investigated by regression analysis, and was found to be highly significant (for benzylpenicillin against cephaloridine, $0.0 \mathrm{I}>P>0.00 \mathrm{r}$; for benzylpenicillin against cephalothin, $P<0.001$ ).

Removal or modification of the functional group in the 3 -sidechain of cephalosporins can cause significant changes in biological activity (Chauvette et al. 1963). It was therefore considered necessary to examine the possibility that such a reaction might be responsible for some or all of the loss of activity observed in these experiments. Samples of cephalothin and cephaloridine which had been incubated in the presence and in the absence of the various staphylococcal strains were consequently subjected to chromatography. In no case was more than one spot apparent when the chromatograms were developed (whether by bioautography or by ultraviolet irradiation). Desacetylcephalosporins run more slowly in the commonly used chromatography

Table $4 . R_{F}$ values of cephaloridine and cephalothin in different solvent systems

\begin{tabular}{|c|c|c|c|c|}
\hline \multicolumn{5}{|c|}{$\begin{array}{l}\text { Acid solvent: } n \text {-butanol + acetic acid + water, } 12+3+5 \text { by vol. } \\
\text { Neutral solvent: } n \text {-butanol + ethanol + water, } 4+1+5 \text { by vol. } \\
\text { Alkaline solvent: } n \text {-butanol + pyridine + water, equal vols. }\end{array}$} \\
\hline & & $\begin{array}{l}\text { Acid } \\
\text { Solvent }\end{array}$ & $\begin{array}{l}\text { Neutral } \\
\text { solvent }\end{array}$ & $\begin{array}{l}\text { Alkaline } \\
\text { solvent }\end{array}$ \\
\hline Substance & development & & $R_{F}$ values & \\
\hline Cephaloridine & $\begin{array}{l}\text { Bioautography } \\
\text { Ultraviolet radiation }\end{array}$ & $\begin{array}{l}0.54(6) \\
0.52(4)\end{array}$ & $0.34(4)$ & $0.73(2)$ \\
\hline Cephalothin & $\begin{array}{l}\text { Bioautography } \\
\text { Ultraviolet radiation }\end{array}$ & $\begin{array}{l}0 \cdot 78(2) \\
0 \cdot 82(4)\end{array}$ & $0.53(4)$ & $0.80(2)$ \\
\hline
\end{tabular}

solvents than do their parent compounds (see the figures given for cephalosporin C/desacetylcephalosporin C by Jeffery, Abraham \& Newton, I96I, and for cephaloram/ desacetylcephaloram by O'Callaghan \& Muggleton, 1963). This also applies to cephalothin/desacetylcephalothin (C. H. O'Callaghan, personal communication: using paper buffered at pH 6.0, the $R_{F}$ value of desacetylcephalothin in butanol + ethanol + water, $4+\mathrm{I}+5$ by vol., is $90 \%$ that of cephalothin, and in propanol + water, $7+3$, by vol. the corresponding figure is $85 \%$ ). Special attention was hence made to seek a spot with an $R_{F}$ value less than that of cephalothin (see Table 4). No such spot was ever found, even in overloaded chromatograms (Io $\mu \mathrm{g}$. nominal spot of cephalothin or cephaloridine). Assuming desacetylcephalothin to have about one-quarter of the activity of cephalothin (Wick, I966), any amount of the former greater than about I $\mu \mathrm{g}$. would be detectable by using the system which was employed in these experiments Since no trace was found on any occasion, it may be assumed that hydrolysis of the 3-sidechain did not, by itself, contribute significantly to the decrease in biological 
activity which was observed under the assay conditions. Furthermore, on chemical grounds (Cocker et al. I965) it is extremely unlikely that the pyridinium group of cephaloridine would be removed (or exchanged for some other nucleophile) in aqueous solutions such as used in these experiments, unless the $\beta$-lactam ring were first broken, in which case the product would be biologically inactive. Thus, the findings reported in this paragraph, taken in conjunction with the correlation between activity against benzylpenicillin and that against cephalosporins, suggest that the cephalosporins are inactivated by hydrolysis of the $\beta$-lactam ring mediated by staphylococcal penicillinase.

\section{DISCUSSION}

The finding that cephaloridine was more rapidly hydrolysed by staphylococcal penicillinase than was cephalothin is in line with the experience of Crompton et al. (I962), who reported that replacement of the acetoxy group of a cephalosporin by a pyridinium group increased the lability of the $\beta$-lactam ring. The evidence presented in the present paper shows that the methicillin-resistant staphylococci used did not have a special ability to hydrolyse cephaloridine, except in as much that such strains tend to produce larger amounts of the enzyme than do methicillin-sensitive strains (Richmond, Parker, Jevons \& John, 1964). With the staphylococcal strains used here there was no significant difference between rates of benzylpenicillin hydrolysis by the two groups. Although these experiments showed that cephaloridine was about I5 times more labile than cephalothin, it must be stressed that the $V_{\max }$ for cephaloridine of staphylococcal penicillinase is only about a five-hundredth that of benzylpenicillin. Furthermore, cephaloridine is stable enough to staphylococcal penicillinase to act as a competitive inhibitor of the enzyme (Hamilton-Miller, 1966). The papers of Benner et al. (1965), Ridley \& Phillips (1965) and Hye-Knudsen (1966), although their findings are not expressed in quantitative terms, might be interpreted as implying that cephaloridine is very labile to staphylococcal penicillinase; such a finding cannot be reconciled with the clinical and laboratory results (as regards penicillinase-producing Staphylococcus aureus) of, for example, Apicella, Perkins \& Saslaw (I966), Vymola \& Hejzlar (I966), Thornton \& Andriole (I966). In the first published report on cephaloridine, Barber \& Waterworth (1964) found that it was more effective than either cephalothin or methicillin against both large and small inocula of 5 methicillinresistant strains of $S$. aureus. Seligman \& Hewitt (I966) reported that cephaloridine was more effective in vitro than cephalothin against intrinsically resistant $S$. aureus strains; this finding has been confirmed in the present work (Table 2), although the degrees of intrinsic resistance were still too high for these strains to be regarded as fully sensitive to cephaloridine.

When cephaloridine solutions were incubated at $37^{\circ}$ for $4 \mathrm{hr}$ in buffer (a procedure carried out each time rates of breakdown of this compound were determined by biological assay), about $10 \%$ of the original biological activity was lost, and the solutions had an odour of pyridine. Such incubation mixtures contained neither a detectable amount of any biologically active metabolite (e.g. a hypothetical 'despyridinium' derivative), nor any new compound detectable by ultraviolet irradiation. These findings suggest that pyridine is expelled from the cephaloridine molecule only as a consequence of fission of the $\beta$-lactam ring (under which circumstances expulsion of pyridine is known to be spontaneous; Sabath, Jago \& Abraham, I965). Thus, the 
loss in activity of the control solutions of cephaloridine can be explained by spontaneous rupture of the $\beta$-lactam ring as the primary reaction. Control solutions of cephalothin did not lose any biological activity after incubation at $37^{\circ}$ for $6 \mathrm{hr}$; this may reflect the greater intrinsic stability of the $\beta$-lactam ring in the cephalothin molecule.

Care must be taken in the interpretation of data about the stability of 'penicillinasestable' $\beta$-lactam antibiotics to staphylococcal penicillinase, especially when comparing results obtained with high substrate concentrations (when, for instance, relative stabilities are measured by a chemical method) with those obtained at low concentrations (e.g. when measurements are made by a biological method). To take a specific example: Smith, Hamilton-Miller \& Knox (1962) reported that the rate of hydrolysis

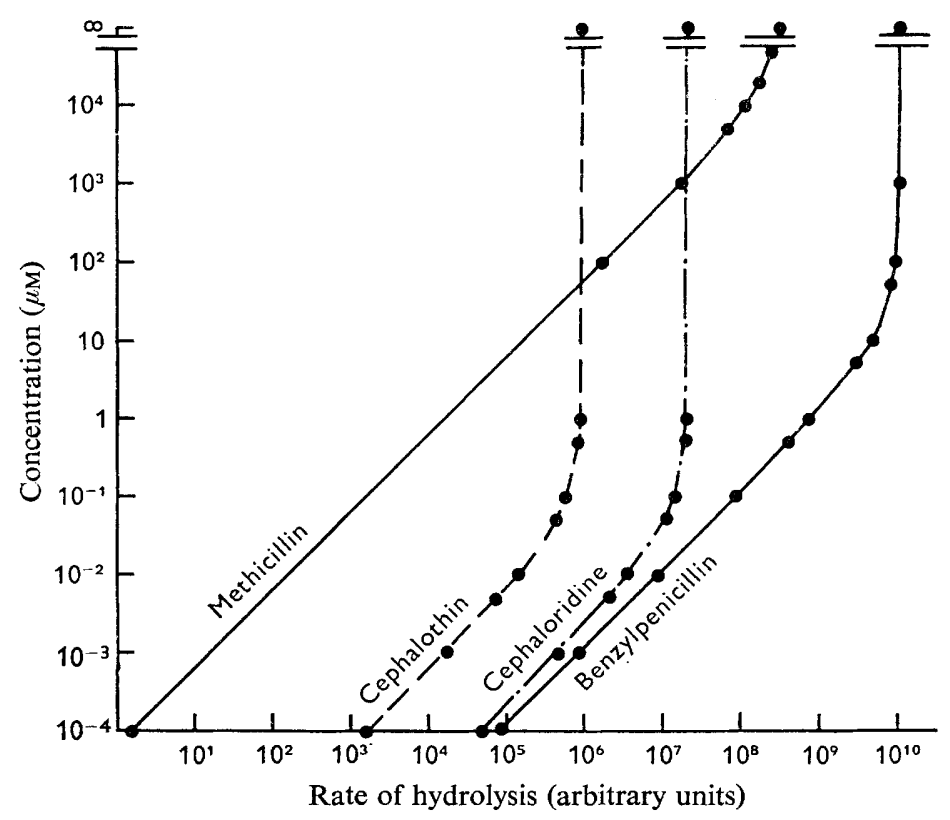

Fig. I. Theoretical rates of hydrolysis of benzylpenicillin, cephaloridine, cephalothin and methicillin by penicillinase from Staphylococcus aureus E3. Rates calculated from MichaelisMenten equation, $v=\left(V_{\max } S\right) /\left(K_{m}+S\right)$, taking the following values of $V_{\max }$ and $K_{m}$ : benzylpenicillin, I00, and $12.3 \mu \mathrm{M}$; cephaloridine, 0.18 , and $0.045 \mu \mathrm{M}$; cephalothin, 0.007 , and $0.056 \mu \mathrm{M}$; methicillin, 3, and $18 \mathrm{~mm}$, respectively (Smith et al. 1962; Hamilton-Miller, unpublished results, and data presented in Table 3).

of methicillin (initial concentration $4.7 \mathrm{~mm}$ ) was about $0.7 \%$ that of the $V_{\max }$ for benzylpenicillin. The $K_{m}$ for methicillin was about $18 \mathrm{~mm}$. From these figures it is possible to calculate by assuming Michaelis-Menton kinetics that, at Io $\mu \mathrm{M}$ (a therapeutically attainable concentration), methicillin will be hydrolysed at a rate which is only about $0.0019 \%$ that of the $V_{\max }$ for benzylpenicillin. A similar argument applies to the isoxazolyl penicillins, but specific figures cannot be given, since $K_{m}$ values for these compounds cannot be accurately measured (Richmond, I965). As pointed out above, cephaloridine and cephalothin have extremely low $K_{m}$ values, and hence will be hydrolysed at maximal rates even when at therapeutic concentrations. Thus, it is possible to draw up two completely separate lists to illustrate the order of lability of 
these compounds. List I, from data obtained at substrate concentrations of the order of $2 \mathrm{mg} . / \mathrm{ml}$., will show in descending order of lability: benzylpenicillin, cloxacillin, methicillin, cephaloridine, cephalothin. List 2, from data obtained at a therapeutically attainable concentration (e.g. $10 \mu \mathrm{M}$ ) will show in descending order of lability: benzylpenicillin, cephaloridine, cephalothin, cloxacillin, methicillin. It is clear that list 2 will be the more useful in working out correlations between penicillinase-lability and activity against penicillinase-producing staphylococci in a series of "penicillinasestable' compounds. The situation is represented graphically in Fig. I.

We are grateful to Professor R. Knox for his comments on the manuscript of this paper, and to Professor E. P. Abraham, F.R.S., and Dr G. G. F. Newton for helpful discussions. The work was done while J.M.T.H.-M. (at present M.R.C. Junior Research Fellow) was in receipt of a grant from the Guy's Hospital Endowments Fund for Medical Research. We thank Dr P. W. Muggleton and Mrs C. H. O'Callaghan of Glaxo Research Ltd for supplying the cephalosporins, and for valuable information.

\section{REFERENCES}

Apicella, M. A., Perkins, R. L. \& Sasiaw, S. (1966). Cephaloridine treatment of bacterial infections. Am. J. med. Sci. 25x, 266.

BARBer, M. (1964). Naturally occurring methicillin-resistant staphylococci. J. gen. Microbiol. 35, 183.

Barber, M. \& Waterworth, P. M. (1964). Penicillinase-resistant penicillins and cephalosporins. Br. med. J. ii, 344.

Benner, E. J., BennetT, J. V., Brodie, J. L. \& Kirby, W. M. M. (1965). Inactivation of cephalothin and cephaloridine by Staphylococcus aureus. J. Bact. 90, I 599.

Chauvette, R. R., Flynn, E. H., Jackson, B. G., Lavagnino, E. R., Morin, R. B., Mueller, R. A., Pioch, R. P., Roeske, R. W., Ryan, C. W., Spencer, J. L. \& van Heyningen, E. (i963). Structure-activity relationships among 7-acylamidocephalosporanic acids. Antimicrobial Agents and Chemotherapy-1962, 687.

Cocker, J. D., Cowley, B. R., Cox, J. S. G., Eardley, S., Gregory, G. I., Lazenby, J. K., Long, A. G., Sly, J. C. P. \& Somerfield, G. A. (1965). Cephalosporanic acids. II. Displacement of the acetoxy-group by nucleophiles. J. chem. Soc. 5015 .

Crompton, B., Jago, M., Crawford, K., Newton, G. G. F. \& Abraham, E. P. (1962). Behaviour of some derivatives of 7-aminocephalosporanic acid and 6-aminopenicillanic acid as substrates, inhibitors and inducers of penicillinases. Biochem. $J .83,52$.

ERICKSEN, K. R. \& ERICHSEN, I. (1963). Resistance to newer penicillins. Br. med. J. i, 746.

Fairbrother, R. W., Parker, L. \& Eaton, B. R. (1954). The stability of penicillinase-producing strains of Staphylococcus aureus. J. gen. Microbiol. xo, 309.

Hamilton-Miller, J. M. T. (1966). A novel method for evaluating $K_{i} / K_{m}$ and its application to the competitive inhibition of staphylococcal penicillinase by cephalosporins. Biochem. $J$. ror, $40 \mathrm{C}$.

Hye-KNudsen, P. (1966). The in vitro activity of cephaloridine. Acta path. microbiol. scand. 66, 54I.

JefFery, J. D'A., Abraham, E. P. \& Newton, G. G. F. (I96I). Deacetylcephalosporin C. Biochem. $J$. $8 \mathrm{I}, 59 \mathrm{I}$.

Jevons, M. P. (I96I). 'Celbenin'-resistant staphylococci. Br. med. J. i, I 24.

KNox, R. (I960). A new penicillin (BRL I24I) active against penicillin-resistant staphylococci. Br. med.J. ii, 690.

KNox, R. \& Smiтh, J. T. (1962). Antibacterial activity, penicillinase stability and inducing ability of different penicillins. J. gen. Microbiol. 28, 47I.

KNOX, R. \& SMith, J. T. (1963). Stability of methicillin and cloxacillin to staphylococcal penicillinase. Br. med. J. ii, 205.

Muggleton, P. W., O'Callaghan, C. \& Stevens, W. K. (1964). Laboratory evaluation of a new antibiotic-cephaloridine (Ceporin). Br. med. J. ii, I234. 
Nayler, J. H. C., Long, A. A. W., Brown, D. M., Acred, P., Rolinson, G. N., Batchelor, F. R. Stevens, S. \& Sutherland, R. (1962). Chemistry, toxicology, pharmacology and microbiology of a new acid-stable penicillin resistant to penicillinase (BRL I621). Nature, Lond. I95, 1264.

O'Callaghan, C. \& Muggleton, P. W. (I963). The formation of metabolites from cephalosporin compounds. Biochem. J. 89, 304.

RICHMOND, M. H. (1965). Wild-type variants of exopenicillinase from Staphylococcus aureus. Biochem. J. 94, 584 .

Richmond, M. H., Parker, M. T., Jevons, M. P. \& John, M. (1964). High penicillinase production correlated with multiple antibiotic resistence in Staphylococcus aureus. Lancet i, 293.

RIDley, M. \& PhILliPS, I. (I965). Relative instability of cephaloridine to staphylococcal penicillinase. Nature, Lond. 208, 1076.

Sabath, L. D., JAGo, M. \& Abraham, E. P. (1965). Cephalosporinase and penicillinase activities of a $\beta$-lactamase from Pseudomonas pyocyanea. Biochem. J. 96, 739.

Seligman, S. J. \& Hewitt, W. L. (1966). Resistance to penicillins and cephalosporins. Antimicrobial Agents and Chemotherapy-1965, 387.

Smith, J. T., Hamilton-Miller, J. M. T. \& Knox, R. (I962). Isoxazolyl penicillins and penicillinase. Nature, Lond. I95, 1300.

Stewart, G. T. \& Holt, R.J. (1963). Evolution of natural resistance to the newer penicillins. Br. med. $J$. i, 308.

Sutherland, R. \& Rolinson, G. N. (I964). Characteristics of methicillin-resistant staphylococci. J. Bact. 87,887 .

Thornton, G. F. \& Andriole, V. T. (I966). Laboratory and clinical studies of a new antibiotic, cephaloridine, in the treatment of Gram-positive infections. Yale J. Biol. Med. 39, 9.

VYMOLA, F. \& HEJZLAR, M. (1966). The classification and characteristics of cephalosporin antibiotics. I. Systematic study of the quantitative sensitivity of some pathogenic microorganisms to cephaloridine. J. Hyg. Epidem. Microbiol. Immun. ro, I80.

WICK, W. E. (1966). In vitro and in vivo laboratory comparison of cephalothin and desacetylcephalothin. Antimicrobial Agents and Chemotherapy-1965, 870. 